\title{
Genetic Investigation in Segregating Generation of Brinjal (Solanum melongena L.)
}

\author{
K. Chithra ${ }^{1}$ - M. Devaraju ${ }^{2}$ V. Srinivasa ${ }^{2}$ B. Varalakshmi ${ }^{3}$ A. B. Asha $^{2}$
}

Received: 3 October 2020/Revised: 15 May 2021/Accepted: 9 July 2021 / Published online: 27 September 2021

(C) The Author(s) 2021

\begin{abstract}
The genetic variability studies indicated that the prevalence of sufficient genetic variation among the genotypes for all the characters. The high Genotypic co-efficient of variation and Phenotypic co-efficient of variation were observed for the number of primary branches and number of fruits per plant. High heritability coupled with high Genetic Advance as per cent of Mean was observed for plant height, number of primary branches, plant spread from North to South, plant spread from East to West, fruit length, fruit diameter, average fruit weight, number of fruits per plant, fruit yield per plant and Total Soluble Solids indicating that these characters are governed by additive gene action. Hence, direct selection may be followed for the improvement of brinjal by assessing these characters.
\end{abstract}

Keywords Brinjal · Variability · Heritability ·

Genetic advance

K. Chithra

chithra3120@gmail.com

1 Department of Vegetable Science, College of Horticulture, Bagalkot, University of Horticultural Sciences, Bagalkot, Karnataka, India

2 Department of Vegetable Science, College of Horticulture, Mudigere, University of Agricultural and Horticultural Sciences, Shivamogga, Karnataka, India

3 Division of Crop Improvement, ICAR-IIHR, Bengaluru, Karnataka, India

\section{Significant Statement}

The success of any crop improvement programme largely depends upon the nature and magnitude of the genetic variability existing in breeding material. So the experiment was conducted to study the genetic variability, heritability and genetic advance in F2 segregating population of the cross Surya $\times$ Harita.

\section{Introduction}

Brinjal also known as eggplant or aubergine is a common vegetable crop grown in tropical and subtropical climates. It is not possible to have one common cultivar to suit different localities. It is therefore required to improve the yield potential of available land races through hybridization, which may yield good hybrids or inbreds. The success of any crop improvement programme largely depends upon the nature and magnitude of the genetic variability existing in breeding material. Effectiveness of selection directly depends on the amount of heritability and genetic advance as per cent of mean for that character. Hence, an insight into the magnitude of variability present in available accessions and hybrids of brinjal is of utmost importance to a plant breeder for starting a judicious breeding program. Therefore, in the current study, an attempt has been made to access the variability in the segregating population of the brinjal hybrid, Surya $\times$ Harita.

\section{Material and methods}

The present investigation was carried out at the Vegetable Science Block in College of Horticulture, Mudigere, University of Agricultural and Horticultural Sciences, 
Shivamogga during the rabi season 2018-2019. The experiment consisted of $300 F_{2}$ plants derived from the cross Surya $\times$ Harita along with their parents, $F_{1}$ hybrids and four checks viz., Arka Harshitha, Arka Keshav, Arka Kusumakar and Devanur Local which were evaluated for yield and yield components. The experiment was laid out in an Augmented Block Design and 30-days-old seedlings were transplanted in $60 \times 45 \mathrm{~cm}$ spacing, and all the recommended agronomic package of practices were followed. Data were recorded on all the $300 F_{2}$ plants, ten randomly selected plants in each of the checks, parents and $F_{1}$ hybrids for 16 characters viz., plant height $(\mathrm{cm})$, number of primary branches, plant spread from North to South $(\mathrm{cm})$, plant spread from East to West $(\mathrm{cm})$, days to first flowering, number of flowers per cluster, number of fruits per cluster, fruit set percentage, days to first picking, fruit length $(\mathrm{cm})$, fruit diameter $(\mathrm{mm})$, average fruit weight $(\mathrm{g})$, number of fruits per plant, fruit yield per plant $(\mathrm{kg})$ and TSS ( ${ }^{\circ}$ brix). The genetic parameters of variability like grand mean, range, phenotypic and genotypic coefficient of variation [1], broad-sense heritability, genetic advance and genetic advance as percentage over mean [2] were calculated.

\section{Estimation of Genetic Parameters}

\section{Genotypic, Phenotypic and Environmental Variances}

Variance due to genotype, phenotype and environment were computed as follows.

Genotypic variance $\left(\sigma^{2} g\right)=\frac{\text { Treatment MSS }- \text { Error MSS }}{r}$

Environmental variance $\left(\sigma^{2} e\right)=$ Error mean sum of squares,

Phenotypic variance $\left(\sigma^{2} p\right)=\sigma^{2} g+\sigma^{2} e$

where, $r$ is the number of replications.

\section{Phenotypic and Genotypic Coefficient of Variation}

Phenotypic coefficient of variation (PCV) and genotypic coefficient of variation $(\mathrm{GCV})$ for all the characters were calculated according to the formula provided by [1] based on the estimate of genotypic and phenotypic variance as follows:

(a)

Phenotypic coefficient of variation $(\mathrm{PCV} \%)=\frac{\sigma^{2} p}{\bar{X}} \times 100$

(b)

Genotypic coefficient of variation $(\mathrm{GCV} \%)=\frac{\sigma^{2} g}{\bar{X}} \times 100$

where, $\sigma^{2} p=$ Phenotypic variance of $F_{2}, \sigma^{2} g=$ Genotypic variance of $F_{2}, X=$ Mean of $F_{2}$ population.
PCV and GCV were classified as $0-10 \%$ as Low, $>$ $10-20 \%$ as Moderate and more than $20 \%$ and above as High.

\section{Heritability ( $h^{2}$ Broadsense)}

Broad-sense heritability was estimated for all the traits using the following formula of [2]

$h^{2}(\%)=\frac{\sigma^{2} g}{\sigma^{2} p} \times 100$

where, $h^{2}=$ Heritability (broad sense) expressed in per cent, $\sigma^{2} g=$ Genotypic variance of $F_{2}$ population, $\sigma^{2-}$ $p=$ Phenotypic variance of $F_{2}$ population.

Heritability percentage was categorized, $0-30 \%$ as Low, $>30-60 \%$ as Moderate and more than $60 \%$ and above as High.

\section{Genetic Advance (GA)}

The extent of genetic advance expected through selection in the $F_{2}$ population for each character was estimated by using the following formula of [2].

$\mathrm{GA}=h^{2} \times K \times \sigma_{\mathrm{p}}$

where, $h^{2}=$ Heritability estimate, $K=$ Selection differential at given intensity (which is equal to 2.06 at 5 per cent intensity of selection), $\sigma_{\mathrm{p}}=$ Phenotypic standard deviation.

Genetic Advance as Per Cent over Mean Genetic advance as per cent over mean was worked out as suggested by [2].

Genetic advance as per cent over mean

$$
=\frac{\mathrm{GA}}{\text { Grand mean }} \times 100
$$

The genetic advance as percent mean was categorized as $0-10 \%$ as Low, $>10-20 \%$ as Moderate and more than $20 \%$ and above classified as High.

Analysis of variance in $F_{2}$ segregating population of the cross Surya $\times$ Harita indicated a significant mean sum of squares attributable to 'treatment' $\left(F_{2}\right.$ progenies + checks), 'tests' ( $F_{2}$ progenies), 'controls' (checks) and 'tests vs controls' for all the traits studied (Table 1). Overall high variability existed for all the characters studied and considerable improvement could be achieved in most of the traits by selection.

The estimates of genetic parameters for growth and yield attributes in $\mathrm{F}_{2}$ segregating population of the bi-parental cross Surya $\times$ Harita were presented in the Table 2 and Fig. 1. High value of GCV and PCV (> 20 per cent) were observed for number of primary branches per plant $(22.10 \% \& 24.91 \%)$ and number of fruits per plant 
Table 1 Analysis of variance in $F_{2}$ segregating population of the bi-parental cross Surya $\times$ Harita for growth and yield parameters

\begin{tabular}{|c|c|c|c|c|c|c|c|c|}
\hline Sl. no. & $\begin{array}{l}\text { Source } \\
\text { Degrees of freedom }\end{array}$ & $\begin{array}{l}\text { Block } \\
9\end{array}$ & $\begin{array}{l}\text { Treatment } \\
303\end{array}$ & $\begin{array}{l}\text { Tests } \\
299\end{array}$ & $\begin{array}{l}\text { Controls } \\
3\end{array}$ & $\begin{array}{l}\text { Tests versus controls } \\
1\end{array}$ & $\begin{array}{l}\text { Error } \\
67\end{array}$ & $\begin{array}{l}\text { Total } \\
379\end{array}$ \\
\hline 1. & Plant height $(\mathrm{cm})$ & $35.16^{*}$ & $158.22 * *$ & $145.86^{* *}$ & $653.80 * *$ & $2368.12 * *$ & 15.68 & 60.01 \\
\hline 2. & Number of primary branches & $1.27 * *$ & $3.13 * *$ & $2.85 * *$ & $28.42 * *$ & $8.38 * *$ & 0.34 & 5.07 \\
\hline 3. & Plant spread from north to south $(\mathrm{cm})$ & 51.84 & $219.54 * *$ & $220.58 * *$ & $135.85^{* *}$ & $159.50^{*}$ & 30.75 & 61.67 \\
\hline 4. & Plant spread from east to west $(\mathrm{cm})$ & $54.43 *$ & $196.55 * *$ & $197.91 * *$ & $92.26 * *$ & $102.54 *$ & 20.89 & 62.22 \\
\hline 5. & Days to first flowering & 0.59 & $14.77 * *$ & $12.93 * *$ & $44.05 * *$ & $478.21 * *$ & 0.51 & 59.48 \\
\hline 6. & Number of flowers per cluster & $0.52 * *$ & $0.48 * *$ & $0.42 * *$ & $1.08 * *$ & $14.00 * *$ & 0.14 & 2.87 \\
\hline 7. & Number of fruits per cluster & $0.16^{*}$ & $0.29 * *$ & $0.19 * *$ & $1.15^{* *}$ & $28.22 * *$ & 0.07 & 1.55 \\
\hline 8. & Fruit set percentage & 90.97 & $246.65^{* *}$ & $218.98 * *$ & $221.31^{*}$ & $8594.05 * *$ & 60.30 & 55.19 \\
\hline 9. & Days to first picking & 0.95 & $14.80 * *$ & $12.94 * *$ & $41.76^{* *}$ & $490.45^{* *}$ & 0.63 & 89.49 \\
\hline 10. & Fruit length $(\mathrm{cm})$ & $1.40 * *$ & $9.14 * *$ & $5.20 * *$ & $129.42 * *$ & $828.87 * *$ & 0.48 & 15.73 \\
\hline 11. & Stalk length $(\mathrm{cm})$ & 0.06 & $0.69 * *$ & $0.68 * *$ & $1.11 * *$ & $3.71 * *$ & 0.20 & 5.93 \\
\hline 12. & Fruit diameter $(\mathrm{mm})$ & 1.49 & $46.02 * *$ & $39.87 * *$ & $58.01 * *$ & $1849.17 * *$ & 2.30 & 31.20 \\
\hline 13. & Average fruit weight $(\mathrm{g})$ & 13.45 & $129.90 * *$ & $129.32 * *$ & $105.44 * *$ & $374.78 * *$ & 11.73 & 52.21 \\
\hline 14. & Number of fruits per plant & 1.09 & $28.33 * *$ & $27.86 * *$ & $5.26 * *$ & $239.54 * *$ & 1.24 & 15.27 \\
\hline 15 . & Fruit yield per plant $(\mathrm{kg})$ & $0.01 * *$ & $0.12 * *$ & $0.11 * *$ & $0.02 * *$ & $1.01 * *$ & 0.002 & 0.80 \\
\hline 16. & Total soluble solids ( ${ }^{0}$ brix) & 0.25 & $1.45^{* * *}$ & $1.35 * *$ & $1.81 * *$ & $30.98 * *$ & 0.13 & 4.61 \\
\hline
\end{tabular}

*Indicates significant @ 5\% level, and **indicates significant @ 1\% level

Table 2 Estimates of genetic parameters for growth and yield attributes in $F_{2}$ segregating population of the bi-parental cross Surya $\times$ Harita

\begin{tabular}{|c|c|c|c|c|c|c|c|c|c|c|c|}
\hline \multirow[t]{2}{*}{ Sl. no. } & \multirow[t]{2}{*}{ Characters } & \multirow[t]{2}{*}{ Mean } & \multicolumn{2}{|l|}{ Range } & \multirow[t]{2}{*}{ GV } & \multirow[t]{2}{*}{ PV } & \multirow[t]{2}{*}{ GCV $(\%)$} & \multirow[t]{2}{*}{$\operatorname{PCV}(\%)$} & \multirow[t]{2}{*}{$h^{2}(\%)$} & \multirow[t]{2}{*}{ GA } & \multirow[t]{2}{*}{ GAM $(\%)$} \\
\hline & & & Min & $\operatorname{Max}$ & & & & & & & \\
\hline 1. & Plant height $(\mathrm{cm})$ & 60.00 & 21.00 & 95.00 & 65.09 & 80.76 & 13.45 & 14.98 & 80.60 & 19.32 & 32.20 \\
\hline 2. & Number of primary branches & 5.07 & 2.00 & 12.00 & 1.26 & 1.60 & 22.10 & 24.91 & 78.68 & 3.39 & 66.83 \\
\hline 3. & Plant spread from north to south $(\mathrm{cm})$ & 61.67 & 26.00 & 100.00 & 94.92 & 125.66 & 15.80 & 18.18 & 75.54 & 23.85 & 38.67 \\
\hline 4. & Plant spread from east to west $(\mathrm{cm})$ & 62.21 & 17.00 & 104.00 & 88.51 & 109.40 & 15.12 & 16.81 & 80.90 & 22.36 & 35.94 \\
\hline 5. & Days to first flowering & 59.48 & 55.00 & 67.00 & 6.21 & 6.71 & 4.19 & 4.36 & 92.55 & 6.26 & 10.53 \\
\hline 6. & Number of flowers per cluster & 2.86 & 1.20 & 5.80 & 0.14 & 0.28 & 13.08 & 18.50 & 50.00 & 1.59 & 55.60 \\
\hline 7. & Number of fruits per cluster & 1.54 & 1.00 & 3.60 & 0.06 & 0.13 & 15.91 & 23.41 & 46.15 & 1.20 & 78.20 \\
\hline 8. & Fruit set percentage & 55.19 & 25.00 & 99.12 & 79.34 & 139.64 & 16.14 & 21.41 & 56.82 & 24.91 & 45.14 \\
\hline 9. & Days to first picking & 89.49 & 85.00 & 97.00 & 6.16 & 6.78 & 2.77 & 2.91 & 90.85 & 6.27 & 7.01 \\
\hline 10. & Fruit length $(\mathrm{cm})$ & 15.72 & 9.90 & 23.90 & 2.36 & 2.84 & 9.77 & 10.72 & 83.10 & 4.30 & 27.37 \\
\hline 11. & Stalk length $(\mathrm{cm})$ & 5.92 & 3.70 & 8.10 & 0.24 & 0.44 & 8.28 & 11.21 & 54.54 & 1.91 & 32.30 \\
\hline 12. & Fruit diameter $(\mathrm{mm})$ & 31.20 & 22.08 & 49.60 & 18.78 & 21.08 & 13.89 & 14.72 & 89.09 & 10.35 & 33.17 \\
\hline 13. & Average fruit weight $(\mathrm{g})$ & 52.20 & 16.66 & 90.00 & 58.80 & 70.53 & 14.69 & 16.09 & 83.37 & 18.13 & 34.74 \\
\hline 14. & Number of fruits per plant & 15.27 & 8.00 & 38.00 & 13.31 & 14.54 & 23.89 & 24.97 & 91.54 & 8.77 & 57.44 \\
\hline 15. & Fruit yield per plant $(\mathrm{kg})$ & 1.48 & 0.36 & 2.40 & 0.05 & 0.06 & 15.70 & 15.99 & 96.43 & 1.45 & 98.09 \\
\hline 16. & Total soluble solids ( ${ }^{0}$ brix $)$ & 4.61 & 2.34 & 8.45 & 0.61 & 0.74 & 16.94 & 18.66 & 82.43 & 2.60 & 56.32 \\
\hline
\end{tabular}

$G V$ genotypic variance, $G C V$ genotypic coefficient of variance, $h^{2}$ heritability (broad sense), $P V$ phenotypic variance, $P C V$ phenotypic coefficient of variance, $G A$ genetic advance, $G A M$ genetic advance as per cent of mean

(23.89\% \& 24.97\%). The difference between PCV and GCV being very low for majority of the characters suggesting more prevalence of genetic governance of these characters and thus selection on phenotypic basis would hold good. These findings are consistent with those of previous researchers [3-5].

High estimates of heritability coupled with higher genetic advance as per cent of mean were observed for 


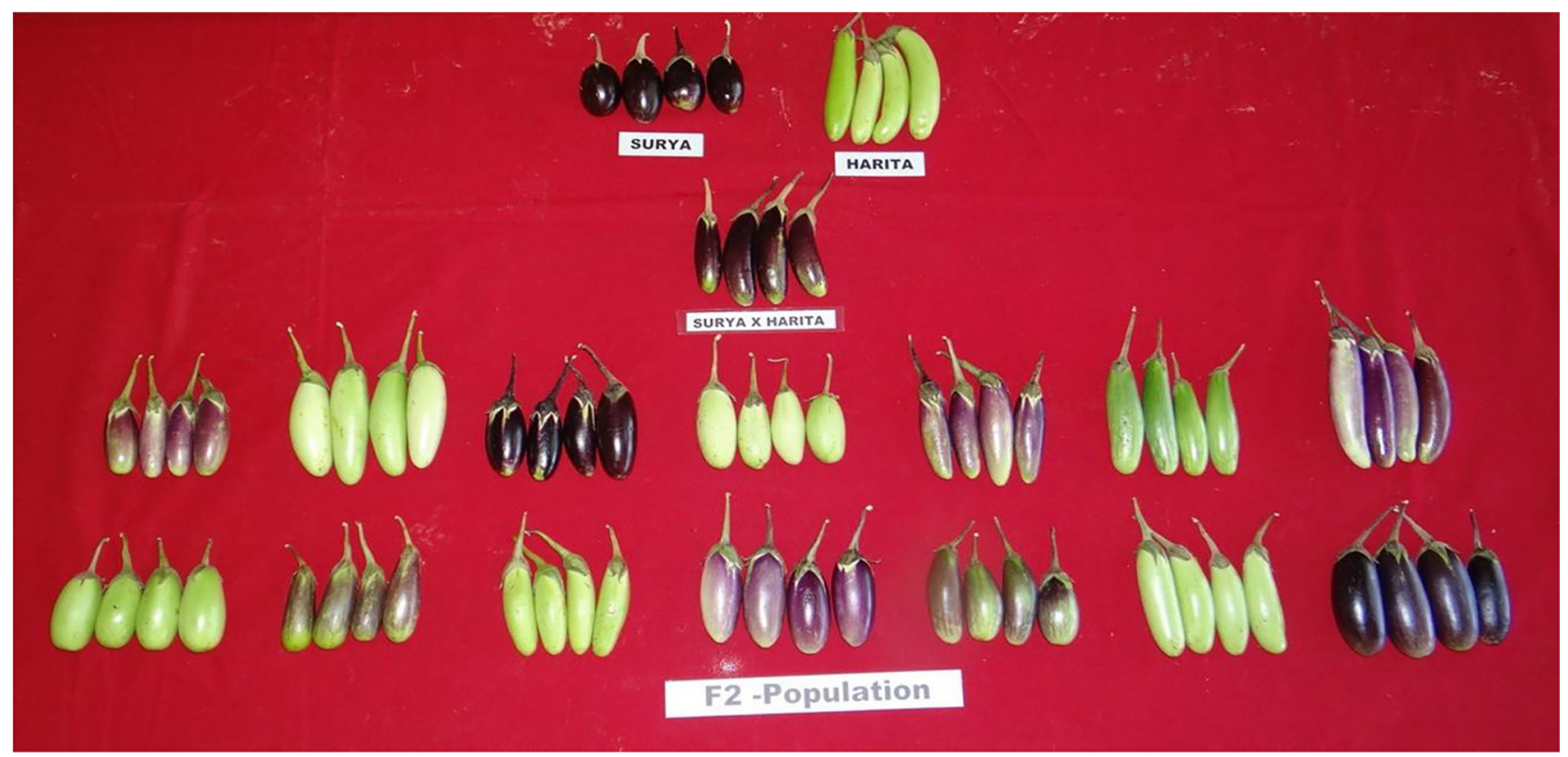

Fig. 1 Variability in $F_{2}$ segregating population of the bi-parental cross Surya $\times$ Harita

plant height $(80.60 \% \& 32.20 \%)$, number of primary branches $(78.68 \% \& 66.83 \%)$, plant spread from North to South $(75.54 \%$ \& $38.67 \%)$, plant spread from East to West $(80.90 \%$ \& $35.94 \%)$, fruit length $(83.10 \% \& 27.37 \%)$, fruit diameter $(89.09 \% \& 33.17 \%)$, average fruit weight $(83.37 \%$ \& $34.74 \%)$, number of fruits per plant $(91.54 \% \&$ $57.44 \%)$, fruit yield per plant $(96.43 \% \& 98.09 \%)$ and TSS $(82.43 \% \& 56.32 \%)$. This indicates the role of additive gene action in the expression of these characters. Hence, simple selection method can be employed for the improvement of these characters. These results are in agreement with earlier workers $[6,7]$.

Acknowledgements This study was carried out and financially supported by the College of Horticulture, Mudigere, University of Agricultural and Horticultural Sciences, Shivamogga to study the genetic investigation in segregating generation of brinjal (Solanum melongena L.). The author is very thankful to Devaraju and Srinivasa $\mathrm{V}$ from department of Vegetable Science, College of Horticulture, Mudigere for their support throughout the study.

Open Access This article is licensed under a Creative Commons Attribution 4.0 International License, which permits use, sharing, adaptation, distribution and reproduction in any medium or format, as long as you give appropriate credit to the original author(s) and the source, provide a link to the Creative Commons licence, and indicate if changes were made. The images or other third party material in this article are included in the article's Creative Commons licence, unless indicated otherwise in a credit line to the material. If material is not included in the article's Creative Commons licence and your intended use is not permitted by statutory regulation or exceeds the permitted use, you will need to obtain permission directly from the copyright holder. To view a copy of this licence, visit http://creativecommons. org/licenses/by/4.0/.

\section{References}

1. Burton GW, Devane EH (1953) Estimating heritability in tall fescue (Festuca arundinacea) from replicated clonal material. Agron J 45:418-481

2. Johnson HW, Robinson HF, Constock RE (1955) Estimate of genetic and environmental variability in soyabeans. Apron $\mathrm{J}$ 47:314-318

3. Devaraju IKM, Srinivasa V, Lakshmana D, Singh TH, Devappa V, Venugopalan R (2020) Breeding potential of brinjal (Solanum melongena L.) genotypes using $\mathrm{D}^{2}$ analysis under hill zones of Karnataka, India. Int J Curr Microbiol Appl Sci 9:2768-2773

4. Magar PG, Shinde KG, Bhalekar MN, Magar VG (2017) Genetic variability studies in brinjal (Solanum melongena L.). Contemp Res India 7:2137-2231

5. Mamatha A, Devaraju K, Premchand U (2017) Studies on variability, heritability and genetic advance in chilli genotypes under hill zone of Karnataka. Res Environ Life Sci 10:467-470

6. Sujin SG, Karuppaiah P, Saravanan K (2017) Genetic variability and correlation studies in brinjal (Solanum melongena L.). Indian J Agric Res 51:112-119

7. Swetha HR (2018) Breeding potential of four crosses for quantitative traits in cowpea (Vigna aunguiculata (L.) Walp.). M.Sc. thesis, GKVK, Bangalore, India, pp 90-92

Publisher's Note Springer Nature remains neutral with regard to jurisdictional claims in published maps and institutional affiliations. 